\title{
CROATIA AS A TOURIST DESTINATION FROM THE PERSPECTIVE OF TOURISTS FROM SERBIA
}

Armed conflicts during the 1990s led to the breakup of Yugoslavia and subsequent deterioration of relations between Yugoslav nations, particularly Serbs and Croats. Twenty-odd years later, the situation is greatly improved and tourism is regarded as an important factor for promoting peace in both countries. In the recent years, Croatia has been making great efforts through its tourism development strategy to remind Serbian tourists of the charm and beauty of the Croatian coast. In this article, the authors present the results of a survey conducted from December 2012 to March 2014 involving 850 residents from Serbia. The aim of the research was to determine how satisfied Serbian tourists are with Croatia as a tourist destination. The results of factor analysis single out five dimensions of visitor satisfaction of Serbian respondents: 'Tourist infrastructure', 'Services', 'Coast maintenance', 'Safety' and 'Communications'. Authors point out that the general attitude towards Croatia can be explained through 'Coastal maintenance' as the most dominant factor. Destinations which visitors from Serbia choose as the most attractive and the safest are coastal places in the northwest part of Croatia (Istra), whereas inland Croatia and southern parts of the Croatian coastline are still not singled out as potential tourist destinations.

Regardless of the above, this research shows that tourism may play a part in the development of peaceful relations between the two nations.

Keywords: Croatia, Serbia, tourism, visitor satisfaction

* Department of Geography, Tourism and Hotel Management, Faculty of Sciences, University of Novi Sad, Serbia. E-mail: ivana.blesic@gmail.com

** Department of Geography, Tourism and Hotel Management, Faculty of Sciences, University of Novi Sad, Serbia. E-mail: tatjana.pivac@dgt.uns.ac.rs

*** Department of Geography, Tourism and Hotel Management, Faculty of Sciences, University of Novi Sad, Serbia. E-mail: atena21000@yahoo.com 


\section{Introduction}

Tourism is one of the most important industries in the Republic of Croatia. Directly or indirectly, it accounts for approx. 22\% of the GDP (gross domestic product) and over $40 \%$ of total export, which inevitably ranks it among the key components of the national economy and foreign trade. Croatia has exceptionally diverse and well preserved natural and cultural tourism potential. The Adriatic Sea and the coastline hold the greatest tourism potential in Croatia. Unique characteristics of the seawater (crystal clear and clean) and relatively sparsely populated shores (the length of the coastline is approx. $1,800 \mathrm{~km}$ with more than 1,000 islands, of which only 66 are populated), together with mild climate, are all well-known landmarks which are used as the main comparative advantage of Croatian tourism ${ }^{1}$.

The year 2012 was a very good year for Croatian tourism, despite the challenges of the global economy and the crisis of the Euro. According to the Croatian Bureau of Statistics, in 2012 the number of tourist arrivals increased by $3.3 \%$ and the number of tourist nights by $4.0 \%$, relative to 2011 . Tourists realized $62,743,463$ tourist nights; $8.3 \%$ by domestic and $91.7 \%$ by foreign visitors mostly from Germany, Slovenia, Austria, the Czech Republic, and Italy. This rate of growth in Croatia and Mediterranean Europe is partly a consequence of traffic shifts from the Middle East and North Africa. Furthermore, Croatia also profited from improved outbound flows from markets such as Scandinavia, Germany and the Russian Federation ${ }^{2}$.

Pursuant to the data from the Croatian Ministry of Tourism, 77,000 of Serbian tourists visited Croatia in 2007. The following year, the number of visits increased to 83,633 , while the number of tourist nights reached 385,093 , i.e. 70,000 more than in 2007. According to these data, Serbia is, along with Japan, the country with the highest rate of visits to Croatia comparing to the previous period. In the opinion of Serbian respondents, Croatia's biggest advantage in tourism development is the beauty of the coast and cultural heritage ${ }^{3}$.

However, comparing to other tourist destinations, travel agencies have a different experience of holiday demands in Croatia. Most of them agree that there is an interest, but in comparison with the favourite, traditional destinations such as Greece, Turkey or Egypt, Croatia is not competitive. According to certain daily newspapers, although Croatia is represented in terms of marketing (with slogans 'Have a holiday where your parents used to have' or 'So beautiful, so

Ministry of Tourism (2003): Croatian Tourism Development by 2010. Republic of Croatia: Strategy Report.

2 Bakšaj Nikola, Toš Stiven (2013): Tourism Overview - Croatia 2013, Croatia: FIMA Securities Ltd.

$3 \quad$ Pivac Tatjana et al. (2016): “The Image of Croation as a Tourist Destination Impression of Serbian Tourists", Tourism Education Studies and Practice 8 (2), 63-71. 
near'), there is no great interest in this destination, primarily due to the prices which are higher than those in Greece or Bulgaria ${ }^{4,5}$. Nevertheless, it can be said that Serbian tourists' interest in spending holidays in Croatia has been consistent during the recent years. According to the data of the National Association of Tourist Agencies (YUTA), approx. 3,500 of Serbian tourists visited Croatia in 2013 (under package tours). There are no precise and reliable estimations of the number of tourists who visited Croatia by themselves, under their own arrangement, but the fact is that that this number is constantly increasing ${ }^{6}$.

\section{Literature review}

Visitor satisfaction has become an important factor in destination management because it is a reliable means of estimating the overall performance. Good comprehension of the level of visitor satisfaction results in beneficial self-service, an activity which focuses on tourism profit, and so do government institutions and private investors whose interest is development of high-quality tourism infrastructure ${ }^{7}$.

There are four groups which affect the choice and decision about a trip:

1) Internal variables (attitudes, values, lifestyle, images, motivation, beliefs and intentions, personal characteristics of a tourist, a phase in life, etc.);

2) External variables (limitations, pull factors of a destination, marketing mix, influence of a family and peer groups, culture and subculture, social class, etc.);

3) The nature of the intended trip (distance to a destination, weather conditions, duration of a trip) and

4) Trip experience (mood and feelings during a trip, later evaluations).

The best destination choice depends on the mutual interaction of all these variables ${ }^{8}$.

In accordance with the theory of customers' behaviour in tourism, visitor satisfaction is the final phase in deciding on a destination, actually a part of rating after the purchase. Increased tourist satisfaction results in the desire to return

http://www.vreme.com/cms/view.php?id=873545

http://www.slobodnaevropa.org/content/srbija_hrvatska_turizam_incidenti/2099885. html

6 http://www.blic.rs/Vesti/Drustvo/395401/Pad-interesovanja-srpskih-turista-za-letovanjeu-Hrvatskoj

Song Haiyan et al. (2011): “Assessing Mainland Chinese Tourists' Satisfaction with Hong Kong Using Tourist Satisfaction Index“, International Journal of Tourism Research 13 (1), 82-96.

8 Sirakaya Ercan, Woodside, G. Arch (2005): Building and testing theories of decision making by travellers, Tourism Management 26, 815-832. 
to that destination i.e. it inspires loyalty and advertises a destination by word of mouth, which is one of the most important means of attracting new tourists ${ }^{9}$.

Research on the visitor satisfaction is one of the most important methods for collecting information on tourist destinations. Tribe \& Snaith (2008) suggested the model of assessing visitor satisfaction with a destination, which they called HOLSAT (holiday satisfaction) ${ }^{10}$. The key characteristic of the HOLSAT model is its capacity to assess visitor satisfaction with a destination rather than a specific service (e.g. hotel service). Also, this model does not use a fixed group of attributes that are common to all destinations. Instead, it allows the use of attributes that are the most appropriate for the observed destination. The model allows tourists to express satisfaction or dissatisfaction by evaluating both positive and negative attributes ${ }^{11}$.

Understanding of visitor satisfaction and visitors' experience of a destination are very important to managers in order to improve products and services, and do effective promotion on the market ${ }^{12}$. Visitor satisfaction can be expressed through the cross-culture perspective, since different cultural values may influence visitors of various cultural backgrounds to experience the provided services and their quality in many different ways. Tourists from different countries put emphasis on different services, such as safety, hygiene, entertainment, staff appearance etc. The guarantee of personal safety is maybe the most important precondition when choosing a destination. Acts of terrorism, crime, natural disasters, and epidemics have negative influence on the image of a destination and represent a big challenge in tourism industry, especially because such safety fears grow with media exposure ${ }^{13},{ }^{14}$. Furthermore, the image of a destination itself has a positive or negative influence on the perception of quality and satisfaction. Positive impression resulting from positive experience will lead to said destination receiving a high rating. Destination image is connected with tourists' behaviour. The better the image, the greater the likelihood of tourists returning to the same place.

$9 \quad$ Geng Q.Christina, Qu Hailin (2008): “Examining the structural relationships of destination image, tourist satisfaction and destination loyalty: An integrated approach", Tourism Management 29, 624-636.

10 Tribe John, Snaith Tim (1998): "From SERVQUAL to HOLSAT: Holiday Satisfaction in Varadero, Cuba", Tourism Management 19 (1), 25-34.

$11 \quad$ Kozak Metin (2001): “Comparative assessment of tourist satisfaction with destinations across two nationalities", Tourism Management 22, 391-401.

$12 \quad$ LeBlanc Gaston (1992): "Factors affecting customer evaluation of service quality in travel agencies: An investigation of customer perceptions", Journal of Travel Research 30 (4), $10-16$.

13 Mansfield Yoel, Pizam Abraham (2005): Tourism, security and safety: From theory to practice, Oxford: Elsevier.

14 Anson Caroline (1999): "Planning for peace: The role of tourism in the aftermath of violence", Journal of Travel Research, 38, 57-61. 
Political impact on tourism trends is strong and multiple: as a means of economic sanctions or embargo; restrictions in tourism industry and tourist activity in order to prevent multinational corporations influencing the local residents; hiding historic events considered to be inappropriate or in some other way politically inadequate, which leads to complete exclusion of certain destinations from tourist product of a country; tourist propaganda of certain countries may be aimed at glorifying certain political ideologies; domestic tourism, especially cultural heritage, is used to build nationalism and patriotism within a country, which is probably one of the most frequent political uses of tourism worldwide ${ }^{15}$.

\section{Methodology}

\subsection{Data collection}

A survey was conducted on the territory of five cities in the Republic of Serbia (Belgrade, Novi Sad, Subotica, Niš, and Kragujevac) from December 2012 to March 2014. The main survey was preceded by a pilot survey $(\mathrm{N}=82)$ carried out in November 2012. Novi Sad and Subotica are situated in the Autonomous Province of Vojvodina, in the north of Serbia. Belgrade is the administrative, political and cultural centre of Serbia, located $190 \mathrm{~km}$ south of Subotica and $90 \mathrm{~km}$ south of Novi Sad. Kragujevac (140 km south of Belgrade) is situated in the central part and Niš (240 km south of Belgrade) in the south of Serbia ${ }^{16}$. All five cities are university centres and residents of smaller nearby places gravitate towards them.

Five researchers participated in the survey, which included residents who visited the Croatian coast at least once. An average time to fill in the questionnaire was ten minutes. A total of 850 valid responses were collected. The sample included $44.8 \%$ males and 55.2\% females among the respondents (Table 1). The two biggest age groups were $41-50$ and $21-30$, which represented $24.7 \%$ and $22.1 \%$ of the respondents, respectively. Most of the respondents (58.6\%) had completed secondary education. Regarding their occupation, the majority of respondents were employed (53.4\%). As for income, the dominant group was the low-income group, with respondents whose monthly income is under $€ 300$ (29.9\%).

\footnotetext{
$15 \quad$ Kim S. Samuel et al. (2007): “Tourism and political ideologies: A case of tourism in North Kore", Tourism Management 28, 1031-1043.

16 Romelić Jovan (2007): Turističke regije Srbije, Novi Sad: PMF, Departman za geografiju, turizam i hotelijerstvo.
} 
Table 1. Socio-demographic characteristics of respondents $(\mathrm{N}=850)$

\begin{tabular}{|c|c|c|}
\hline Variable & $N$ & $\%$ \\
\hline \multicolumn{3}{|l|}{ Age } \\
\hline$\leq 20$ & 146 & 17.2 \\
\hline $21-30$ & 188 & 22.1 \\
\hline $31-40$ & 126 & 14.8 \\
\hline $41-50$ & 210 & 24.7 \\
\hline $51-60$ & 126 & 14.8 \\
\hline$\geq 61$ & 54 & 6.4 \\
\hline \multicolumn{3}{|l|}{ Income } \\
\hline$\leq 300 €$ & 254 & 29.9 \\
\hline $301-500 €$ & 226 & 26.6 \\
\hline $501-700 €$ & 80 & 9.4 \\
\hline $701-1000 €$ & 36 & 4.2 \\
\hline$\geq 1001$ & 25 & 2.9 \\
\hline \multicolumn{3}{|l|}{ Gender } \\
\hline Male & 381 & 44.8 \\
\hline Female & 469 & 55.2 \\
\hline \multicolumn{3}{|l|}{ Education } \\
\hline Secondary education & 498 & 58.6 \\
\hline College & 77 & 9.1 \\
\hline Higher education & 186 & 21.9 \\
\hline Master's degree & 45 & 5.3 \\
\hline Doctor's degree & 12 & 1.4 \\
\hline \multicolumn{3}{|l|}{ Occupation } \\
\hline Pupil & 18 & 2.1 \\
\hline Student & 214 & 25.2 \\
\hline Employed & 454 & 53.4 \\
\hline Retired & 79 & 9.3 \\
\hline Unemployed & 63 & 7.4 \\
\hline Other & 22 & 2.6 \\
\hline
\end{tabular}




\subsection{Questionnaire design}

The questionnaire used in the survey was based on the review of relevant literature ${ }^{17},{ }^{18},{ }^{19}$ and adjusted to the particular research and specific relations between the two nations during the last 25 years. Thirty items were added to the questionnaire based on the literature review and opinions of five members of the focus group (university professors of history and tourism). According to the results of the pilot research $(\mathrm{N}=82)$, eight questions were excluded from the questionnaire due to their low loading factor scores. The redesigned questionnaire contained 22 questions on attitudes of Serbian tourists towards Croatia as a tourist destination. There was one additional question, which would reflect the general attitude of respondents towards Croatia ('Croatia is the country I would gladly visit'). Since the Croatian coast is the most attractive and the most visited part of Croatia, the authors focused their research on the attitudes towards the Croatian coast. According to data of the Ministry of Tourism of the Republic of Croatia, $84 \%$ of all tourist visits in 2013 were to the coastal places ${ }^{20}$. The questionnaire was structured using satisfaction items based on a seven-point Likert's scale. The structure of the scale was based on the following categories: terrible (1), unhappy (2), mostly unsatisfied (3), neither satisfied nor unsatisfied (4), mostly satisfied (5), pleased (6) and delighted (7). The last question in the questionnaire was a gap-filling one, regarding favourite destination on the Croatian coast.

\section{Results}

The data were factor analysed using the principal component method and varimax rotation procedure in order to extract the sub-dimensions. The Kaiser-MeyerOlkin (KMO) overall measure of sampling adequacy was 0.874 and Bartlett's test of sphericity was significant $(p=0.000)$. These results showed that the set of items is suitable for factor analysis ${ }^{21}$. All factors with eigenvalue greater than 1 and with factor loadings exceeding 0.5 were retained. The results of the factor analysis, which suggested a five-factor solution, included 22 attributes and explained $67.47 \%$ of the variance. The results of the factor analysis produced a clean factor structure with

${ }_{17} \quad$ Kim S. Samuel, Prideaux Bruce (2006): "An investigation of the relationship between South Korean domestic public opinion, tourism development in North Korea and a role for tourism in promoting peace on the Korean peninsula", Tourism Management 27, 124-137.

18 Del Bosque I. Rodriguez, San Martin Hector (2008): "Tourist Satisfaction a CognitiveAffective Model", Annals of Tourism Research 35 (2), 551-573.

19 Alegre Joauqin, Garau Jaume (2010): “Tourist Satisfaction and Dissatisfaction", Annals of Tourism Research 37 (1), 52-73.

20 Ministry of Tourism (2014). Tourism in numbers 2013. Republic of Croatia: Strategy Report.

${ }^{21} \quad$ Kaiser F. Henny (1974): An index of factorial simplicity, Psychometrika, 39, 31-36. 
high loadings on the appropriate factors. Most variables loaded heavily on one factor and this indicated that there was minimal overlap among factors and that all factors were independently structured. Cronbach's a values for each factor were greater than 0.7. The results showed that the Alpha coefficients of the seven factors ranged from 0.796 to 0.890 . This demonstrates that the scales of the formal questionnaire have considerable reliability ${ }^{22}$. Table 2 shows the results of the factor analysis.

Table 2. Results of factor analysis

\begin{tabular}{|c|c|c|c|c|c|}
\hline $\begin{array}{l}\text { Extracted } \\
\text { Factors }\end{array}$ & Items & $\begin{array}{l}\text { Factor } \\
\text { loading }\end{array}$ & Eigenvalue & $\begin{array}{l}\text { Variance } \\
\text { explained }\end{array}$ & $\begin{array}{c}\text { Cronbach's } \\
\text { a }\end{array}$ \\
\hline \multirow{6}{*}{$\begin{array}{l}\text { F1 - Tourist } \\
\text { infrastructure }\end{array}$} & Roads in Croatia are quality and safe & .719 & 7.075 & 32.161 & .875 \\
\hline & There is a fair offer of eating establishments & .719 & & & \\
\hline & There is a fair offer of hotels & .785 & & & \\
\hline & Rich cultural heritage & .794 & & & \\
\hline & $\begin{array}{c}\text { There is a wide range of tourist information } \\
\text { centres }\end{array}$ & .713 & & & \\
\hline & Night life & .614 & & & \\
\hline \multirow{5}{*}{ F2 - Services } & $\begin{array}{l}\text { Prices of products and services are } \\
\text { reasonable }\end{array}$ & .618 & 3.088 & 14.034 & .833 \\
\hline & Medical aid for tourists is well organized & .697 & & & \\
\hline & Hotel staff are helpful & .779 & & & \\
\hline & Restaurant staff are helpful & .767 & & & \\
\hline & $\begin{array}{c}\text { Staff in public transport and taxi services are } \\
\text { helpful }\end{array}$ & .621 & & & \\
\hline \multirow{4}{*}{$\begin{array}{l}\mathrm{F} 3-\text { Coast } \\
\text { maintenance }\end{array}$} & $\begin{array}{l}\text { Coastal places are nicely maintained and } \\
\text { clean }\end{array}$ & .756 & 1.979 & 8.997 & .864 \\
\hline & Beaches are clean and well maintained & .805 & & & \\
\hline & $\begin{array}{l}\text { Croatian beaches are attractive because of } \\
\text { lush Mediterranean vegetation }\end{array}$ & .798 & & & \\
\hline & $\begin{array}{c}\text { Sea is clean and water temperature is } \\
\text { pleasant to bathe }\end{array}$ & .757 & & & \\
\hline \multirow{3}{*}{ F4 - Safety } & $\begin{array}{c}\text { Tourist safety on the destination is at a high } \\
\text { level }\end{array}$ & .823 & 1.476 & 6.708 & .890 \\
\hline & $\begin{array}{l}\text { I spoke freely in Serbian language on a } \\
\text { beach/in a shop/in a hotel }\end{array}$ & .923 & & & \\
\hline & $\begin{array}{l}\text { I did not have any problems because I come } \\
\text { from Serbia }\end{array}$ & .899 & & & \\
\hline \multirow{4}{*}{$\begin{array}{c}\text { F5 - } \\
\text { Communications }\end{array}$} & $\begin{array}{l}\text { At the destination I spoke with local people } \\
\text { about the war and the breakup of Yugoslavia }\end{array}$ & .740 & 1.225 & 5.570 & .796 \\
\hline & $\begin{array}{l}\text { At the destination I spoke with local people } \\
\text { about the living conditions in Serbia and } \\
\text { Croatia }\end{array}$ & .828 & & & \\
\hline & $\begin{array}{l}\text { At the destination local people spoke with } \\
\text { me of their own accord }\end{array}$ & .783 & & & \\
\hline & I wanted to communicate with other tourists & .731 & & & \\
\hline
\end{tabular}

Kaiser-Meyer-Olkin measure of sampling adequacy: 0.874 Bartlett's test of sphericity: 10251.428 ; significance: 0.000 .

22 Nunnally C. Jum (1978): Psychometric theory, New York: McGraw-Hill. 
The first factor was labelled 'Tourist infrastructure'. This factor explained $32.161 \%$ of the total variance with a reliability coefficient of 0.875 . The second factor was 'Services' explaining $14.034 \%$ of the total variance with a reliability coefficient of 0.833 . The third factor was labelled 'Coast maintenance' and explained $8.997 \%$ of the variance with a reliability coefficient of 0.864 . The fourth factor, labelled 'Safety' accounted for $6.708 \%$ of the variance with a reliability coefficient of 0.890 . The fifth dimension 'Communications', accounted for $5.570 \%$ of the variance with a reliability coefficient of 0.796 .

Table 3. Mean ratings of factors and items

\begin{tabular}{|c|c|c|}
\hline Selected factors and items & $\bar{X}$ & $\sigma$ \\
\hline F1 - Tourist infrastructure & 5.227 & 1.055 \\
\hline Roads in Croatia are quality and safe & 5.389 & 1.339 \\
\hline There is a fair offer of eating establishments & 5.363 & 1.388 \\
\hline There is a fair offer of hotels & 5.314 & 1.350 \\
\hline Rich cultural heritage & 5.336 & 1.328 \\
\hline There is a wide range of tourist information centres & 4.880 & 1.339 \\
\hline Night life & 5.080 & 1.321 \\
\hline F2 - Services & 4.455 & 1.163 \\
\hline Prices of products and services are reasonable & 3.760 & 1.504 \\
\hline Medical aid for tourists is well organized & 4.521 & 1.388 \\
\hline Hotel staff are helpful & 4.755 & 1.524 \\
\hline Restaurant staff are helpful & 4.792 & 1.550 \\
\hline Staff in public transport and taxi services are helpful & 4.445 & 1.541 \\
\hline F3 - Coast maintenance & 5.447 & 1.206 \\
\hline Coastal places are nicely maintained and clean & 5.622 & 1.424 \\
\hline Beaches are clean and well maintained & 5.503 & 1.359 \\
\hline Croatian beaches are attractive because of lush Mediterranean vegetation & 5.170 & 1.451 \\
\hline Sea is clean and water temperature is pleasant to bathe & 5.494 & 1.488 \\
\hline F4 - Safety & 4.051 & 1.900 \\
\hline Tourist safety on the destination is at high level & 4.068 & 2.052 \\
\hline I spoke freely in Serbian language on a beach/in a shop/in a hotel & 4.015 & 2.104 \\
\hline I did not have any problems because I come from Serbia & 4.071 & 2.140 \\
\hline F5 - Communications & 3.265 & 1.567 \\
\hline $\begin{array}{c}\text { At the destination I spoke with local people about the war and the } \\
\text { breakup of Yugoslavia }\end{array}$ & 2.571 & 1.997 \\
\hline $\begin{array}{l}\text { At the destination I spoke with local people about the living conditions in } \\
\text { Serbia and Croatia }\end{array}$ & 3.212 & 2.111 \\
\hline At the destination local people spoke with me of their own accord & 3.369 & 1.872 \\
\hline I wanted to communicate with other tourists & 3.908 & 1.973 \\
\hline
\end{tabular}


Results of the descriptive statistical analysis presented in Table 3 show that respondents are mostly satisfied with the attributes referring to beauty and maintenance of the Croatian coast $(\bar{X}=5,45 ; \sigma=1,21)$. The Croatian coast offers not only clear and clean sea water but also a number of various beaches cowered with dense Mediterranean vegetation. Another highly rated factor is tourist infrastructure ( $\overline{\mathrm{X}}=5.23 ; \sigma=1.06)$. Croatia has a modern network of motorways throughout the whole country. They are mostly directed north-south, connecting the Adriatic coast with large cities in the north of the country and farther on to central and west Europe. Also, the hospitality industry in this country is very well developed, with quality hotel capacities and restaurants with a wide range of dishes. Croatia has five cultural heritage sites (Historical complex Split and Diocletian's Palace, The old town of Dubrovnik, Euphrasian Basilica in Poreč, Historical Town of Trogir and St. Jacob's Cathedral in Šibenik) and two nature reserves (National Park Plitvice and Starogradsko polje Hvar), all under the protection of UNESCO. The lowest rated factor is communication ( $\overline{\mathrm{X}}=3.27 ; \sigma=1.57$ ), namely social contacts and communication between local people and tourists. More than two decades after the armed conflicts, people still reluctantly speak about the topics connected with the breakup of Yugoslavia, but also some other matters such as economy and political situation in the region.

The question referring to the favourite destination on the Croatian coast and the reason why people chose it gave some interesting results. Approx. 79.2\% of respondents answered this question by choosing places in Istra, the northernmost part of the Croatian coast (Rovinj, Pula, Umag, Poreč, and Rijeka). The most frequent motive for such choice was that respondents felt safe in this part of Croatia (35.3\%) and that they enjoyed the unspoiled nature (30.7\%). According to a daily newspaper, the fact that residents of Serbia (in view of the Croatian coast) mostly opt for Istra was also published in a newspaper article stating that Serbs are coming back to Istra and that Pula and Rovinj remained their favourite summer holiday destinations ${ }^{23}$.

Standard (simultaneous) multiple regression was used to rate the possibility to predict overall visitor satisfaction. Regression analyses were used to determine connections where one phenomenon (independent variable or cause) influences the other one (dependent variable or consequence). The question used to express respondents' attitude towards Croatia $(\bar{X}=4.71 ; \sigma=1.34)$ is marked as a dependent variable. Factors which determine visitor satisfaction with Croatia as a tourist destination (tourist infrastructure, services, maintenance of the coast, safety, and communication) are marked as independent variables.

23 http://www.telegraf.rs/vesti/1483157-hrvati-uradili-nesto-neocekivano-pula-se-zahvaljuje-srbiji-foto 
Table 4. Favourite tourist destinations in Croatia selected by potential tourists from Serbia

\begin{tabular}{ccc}
\hline Destination & Frequency & $\%$ \\
\hline Pula & 167 & 19.6 \\
Rovinj & 189 & 22.2 \\
Umag & 143 & 16.8 \\
Mali Lošinj & 118 & 13.9 \\
Korčula & 6 & .7 \\
Brač & 9 & 1.1 \\
Hvar & 13 & 1.5 \\
Dubrovnik & 14 & 1.6 \\
Split & 10 & 1.2 \\
Zadar & 6 & .7 \\
Poreč & 104 & 12.2 \\
Rijeka & 71 & 8.4 \\
Total & 850 & 100.0 \\
\hline
\end{tabular}

Table 5. Main reasons for the choice

\begin{tabular}{ccc}
\hline Items & Frequency & $\%$ \\
\hline I feel welcomed & 300 & 35.3 \\
Because of cultural values and historical significance & 102 & 12.0 \\
Because of beautiful beaches and abundant vegetation & 261 & 30.7 \\
Because I have long-standing friends there & 64 & 7.5 \\
Because I have a house there & 62 & 7.3 \\
Because I have relatives there & 61 & 7.2 \\
\hline
\end{tabular}

Table 6. Model of the predictive effect that the satisfaction factors regarding Croatia as a tourist destination have on respondents' general attitude towards Croatia

\begin{tabular}{ccccc}
\hline Model & $R$ & R Square & Adjusted R Square & Std. Error of the Estimate \\
\hline 1 & .672 & .451 & .448 & .995 \\
\hline
\end{tabular}

Predictors: (Constant), F5, F3, F4, F2, F1

The model as a whole explains $45.1 \%$ of total variance (Sig. $=.000$ ). It can be concluded from the column Beta that the major percentage $(52.4 \%)$ of variation of dependent variable (general attitude towards Croatia) can be explained (predicted) by the 'coastal maintenance' dimension. Furthermore, a certain percentage of variation of dependent variable can be explained by the 'services' dimension (15.7\%). The 'safety' dimension explains only $9.1 \%$ of dependent variable. 
The proportion of dimensions 'tourist infrastructure' and 'communication' is small and not statistically significant (Sig. > 0.05). For all intents and purposes, this information shows that the beauty of the Croatian coast is the most dominant factor by which the attitude of the Serbian respondents towards Croatia as a tourist destination can be predicted.

Table 7. Regression quotients of the Model of the predictive effect that the satisfaction factors regarding Croatia as a tourist destination have on respondents' general attitude towards Croatia

\begin{tabular}{ccccccccc}
\hline Model 1 & \multicolumn{2}{c}{$\begin{array}{c}\text { Unstandardized } \\
\text { Coefficients }\end{array}$} & $\begin{array}{c}\text { Standardized } \\
\text { Coefficients }\end{array}$ & T & Sig. & \multicolumn{3}{c}{ Correlations } \\
& B & Std. Error & Beta & & & Zero-order & Partial & Part \\
\hline F1 & .070 & .196 & & .359 & .719 & & & \\
F2 & .072 & .043 & .057 & 1.665 & .096 & .463 & .057 & .042 \\
F3 & .180 & .039 & .157 & 4.654 & .000 & .431 & .158 & .119 \\
F4 & .582 & .035 & .524 & 16.409 & .000 & .636 & .492 & .418 \\
F5 & .064 & .019 & .091 & 3.310 & .001 & .253 & .113 & .084 \\
\end{tabular}

Dependent Variable: Croatia is the country I would gladly visit.

\section{Conclusion}

Whether the new Balkan countries will efficiently overcome their histories of violence and manage to establish successful and sustainable tourism development mostly depends on the level at which all participants are completely and cooperatively involved in the process of destination branding. This is still a complex economic and political problem for societies in transition ${ }^{24}$.

Results of the research conducted by $\operatorname{Kim} \&$ Prideaux $(2003,2006)$ show that tourism does have a part in reducing tension by increasing opportunities for mutual contacts between people of the countries at war $^{25},{ }^{26}$. Although results of this survey were not aimed at determining the influence of tourism on improving the relations between the two nations (Serbs and Croats), results of regression analysis show that the beauty of the Croatian coast is strongly represented in

$24 \quad$ Vitić Andriela, Greg Ringer (2007): "Branding post-conflict destinations: Recreating Montenegro after the disintegration of Yugoslavia", Journal of Travel and Tourism Marketing 23, 127-137.

25 Kim, S. Samuel, Prideaux Bruce (2003): “Tourism, peace, politics and ideology: impacts of the Mt. Gumgang tour project in the Korean Peninsula", Tourism Management 24(6), 675-685.

26 Kim S. Samuel, Prideaux Bruce (2006) 
explaining the general attitude of Serbian respondents towards Croatia as a destination. This proves that the appeal of the Croatian coast, as well as the nostalgic feeling connected with it, have contributed to the return of Serbian tourists. The results of this survey are significant from three perspectives. Firstly, there has been no research into the attitudes of Serbian tourists towards Croatia as a destination until now. Secondly, a reliable model was set (Cronbach's a values for each factor were greater than 0.7 ) to assess visitor satisfaction with destinations of sun \& sand tourism, and it is appropriate for observing similar examples of post-war relations between the two nations. Thirdly, results of this research have shown that tourism plays a part in the development of peaceful relations between hostile nations and that tourism values of a destination may influence the returning of tourists who evoke pleasant memories of that destination.

Limitations of this study are connected with an impossibility of continuous observation of statistical data referring to the number of Serbian tourists in the post-war times. One of the problems is that the official statistics does not keep records of unregistered private accommodations which are a dominant type of accommodation for Serbian tourists.

The authors of the paper believe that the results of this research would be more indicative if there is feedback on the attitude the local population in Croatia has towards the Serbian tourists. The future research of these authors will be aimed at setting an adequate model which will address this problem. It has also been noticed that there is a need to keep accurate records of the ways in which the two nations perceive tourism, which will be realized through longitudinal research. Bilateral aspects of international tourism industry are becoming more and more important and thus require more attention than before.

\section{Acknowledgements}

This study resulted as a part of National project of Ministry of Science and Technological Development: 'Social relationship between Serbs and Croats, national identity and minority rights with regard to European integration', No. 47024. and the "Ethnic groups of Vojvodina in the 21st century - the state and prospects of sustainability" number 114-451-2539 / 2016-02 funded by the Provincial Secretariat for higher education and scientific research. 


\section{Literature}

- Alegre Joauqin, Garau Jaume (2010): “Tourist Satisfaction and Dissatisfaction", Annals of Tourism Research 37 (1), 52-73.

- Anson Caroline (1999): Planning for peace: The role of tourism in the aftermath of violence", Journal of Travel Research, 38, 57-61.

- Bakšaj Nikola, Toš Stiven (2013): Tourism Overview - Croatia 2013, Croatia: FIMA Securities Ltd.

- Geng Q.Christina, Qu Hailin (2008): "Examining the structural relationships of destination image, tourist satisfaction and destination loyalty: An integrated approach", Tourism Management 29, 624-636.

- Del Bosque I. Rodriguez, San Martin Hector (2008): "Tourist Satisfaction a Cognitive-Affective Model”, Annals of Tourism Research 35 (2), 551-573.

- Kaiser F. Henny (1974): An index of factorial simplicity, Psychometrika, 39, 31-36.

- Kim, S. Samuel, Prideaux Bruce (2003): “Tourism, peace, politics and ideology: impacts of the Mt. Gumgang tour project in the Korean Peninsula", Tourism Management 24(6), 675-685.

- $\quad$ Kim S. Samuel, Prideaux Bruce (2006): “An investigation of the relationship between South Korean domestic public opinion, tourism development in North Korea and a role for tourism in promoting peace on the Korean peninsula", Tourism Management 27, 124-137.

- Kim S. Samuel., Dallen Timothy \& Han H.Chin (2007): “Tourism and political ideologies: A case of tourism in North Korea", Tourism Management 28, 1031-1043.

- Kozak Metin (2001): "Comparative assessment oftourist satisfaction with destinations across two nationalities", Tourism Management 22, 391- 401.

- LeBlanc Gaston (1992): "Factors affecting customer evaluation of service quality in travel agencies: An investigation of customer perceptions", Journal of Travel Research 30 (4), 10-16.

- Mansfield Yoel, Pizam Abraham (2005): Tourism, security and safety: From theory to practice, Oxford: Elsevier.

- Ministry of Tourism (2003). Croatian Tourism Development by 2010. Republic of Croatia: Strategy Report.

- Ministry of Tourism (2014). Tourism in numbers 2013. Republic of Croatia: Strategy Report. (available on: http://business.croatia.hr/Documents/3256/ Turizam-u-brojkama-2013.pdf, accesed on 20 Jun 2015).

- Nunnally C. Jum (1978): Psychometric theory, New York: McGraw-Hill.

- Pivac Tatjana, Blešić Ivana, Stamenković Igor, Ivanović Bibić Ljubica, Penić Mirjana (2016): "The Image of Croation as a Tourist Destination Impression of Serbian Tourists", Tourism Education Studies and Practice 8 (2), 63-71. 
- Romelić Jovan (2007): Turističke regije Srbije, Novi Sad: PMF, Departman za geografiju, turizam i hotelijerstvo.

- Sirakaya Ercan, Woodside, G. Arch (2005): "Building and testing theories of decision making by travelers", Tourism Management 26, 815-832.

- Song Haiyan, Gang Li, Robert van der Veen and Jason Chen (2011): “Assessing Mainland Chinese Tourists' Satisfaction with Hong Kong Using Tourist Satisfaction Index", International Journal of Tourism Research 13 (1), 82-96.

- Tribe John, Tim Snaith (1998): "From SERVQUAL to HOLSAT: Holiday Satisfaction in Varadero, Cuba", Tourism Management 19 (1), 25-34.

- Vitić Andriela, Greg Ringer (2007): "Branding post-conflict destinations: Recreating Montenegro after the disintegration of Yugoslavia", Journal of Travel and Tourism Marketing 23, 127-137.

- http://www.blic.rs/Vesti/Drustvo/395401/Pad-interesovanja-srpskihturista-za-letovanje-u-Hrvatskoj (accesed on 5 August 2015).

- http://www.vreme.com/cms/view.php?id=873545 (accesed on 5 August 2015)

- http://www.slobodnaevropa.org/content/srbija_hrvatska_turizam_incidenti/2099885.html (accesed on 5 August 2015).

- http://www.telegraf.rs/vesti/1483157-hrvati-uradili-nesto-neocekivano-pula-se-zahvaljuje-srbiji-foto (accesed on 7 August 2015). 


\section{HRVATSKA KAO TURISTIČKA DESTINACIJA IZ UGLA TURISTA IZ SRBIJE}

Ratni sukobi devedesetih godina XX veka doveli su do raspada Jugoslavije i urušili su se odnosi između svih država i naroda koji su činili zajedničku državu. Odnosi između svih naroda su se pogoršali, naročito između Srba i Hrvata. Posle dvadeset godina od ratnih sukoba, situacija se u državama normalizuje, a razvoj turizma može biti dobro sredstvo za promovisanje mira u obe države. Hrvatska poslednjih godina u svojoj strategiji razvoja turizma snažno pokušava da probudi kod srpskih turista nostalgiju i zaboravljenu emociju za hrvatsko primorje. U radu će biti predstavljeni rezultati anketnog istraživanja sprovedenog od decembra 2012. do marta 2014. godine u kojem je učestvovalo 850 rezidenata iz Srbije. Istraživanje je usmereno na utvrdivanje zadovoljstva srpskih turista Hrvatskom kao turističkom destinacijom.

Ključne reči: Hrvatska, Srbija, turizam, zadovoljstvo posetilaca 